\title{
Mentor for a Month: A Case Study at a State University
}

\author{
Nilüfer Evişen, Akın Gürbüz, Lale Kutlar \\ Gaziantep University, Gaziantep, Turkey
}

\begin{abstract}
Starting to work in a new workplace is a challenge for almost anyone regardless of their experience. The same situation applies to teachers when they start their jobs and/or when they move within schools. There are new rules, regulations, student profiles, expectations, and school cultures to become familiar with. Oftentimes, the teacher has to struggle with all these new circumstances alone. Hence, he/she may feel alienated and overloaded. The ideal case would be to assign a mentor for each and every newly arriving teacher, so that he/she could make a smooth transition between the two phases of his/her career. The present study took place at a state university in Gaziantep, Turkey. Having continued for six weeks, it aims at building a bridge between the new teacher and his/her new workplace in order to inform him/her with first-hand knowledge and experience; thus, guiding him/her throughout the beginning stages in the new institution. It also tries to find out what both sides, namely the mentor and the mentee, think about that application. As data collection procedure, a semi-structured interview was conducted with a randomly selected instructor who has been working at the institution for 24 years and an instructor who has been performing the job for seven years but teaching at the mentioned institution for a month only. The two teachers first observed each other for two weeks, and in the remaining four weeks' period, they started to come together at regular intervals - twice every week - to talk about the topic determined by the researchers. The sessions were audio recorded by the two instructors and then transcribed by the researchers. The mentee was also asked to keep a weekly journal about her reflections on what she has been going through. At the end of the study, the researchers came together with the two participating teachers and interviewed them about their beliefs related to the study. Content analysis was carried out to reach the emerging constructs both from the audio recordings and the journal. The findings revealed that both teachers believed in the importance of mentoring a new teacher at least at the beginning of his/her post at the new school and both teachers agreed that it was a fruitful experience for both of them since they had learnt useful clues, different techniques, and new points of view from each other. The results are discussed in the light of relevant literature. The findings of the study are expected to contribute to the literature as well as shedding light on how to enhance the practical applications of mentoring studies by administrators of schools, policy-makers, and individual teachers as a kind of a professional development activity.
\end{abstract}

Keywords: mentoring, mentee, professional development

Nilüfer Evişen, instructor, Ph.D. candidate, Higher School of Foreign Languages, Gaziantep University, Gaziantep, Turkey. Akın Gürbüz, instructor, Ph.D. candidate, Higher School of Foreign Languages, Gaziantep University, Gaziantep, Turkey. Lale Kutlar, instructor, M.A., Higher School of Foreign Languages, Gaziantep University, Gaziantep, Turkey. 


\section{Introduction}

Along with experts and interested teachers, there are a remarkable number of teachers who have heard about the term "mentoring" a lot of times over the past few years. It is almost impossible not to have heard of the word. Although quite a lot of professionals on the field are familiar with the concept, it is still debatable how many teachers know the core meaning of "mentoring". Mentoring means helping and supporting a comparatively new teacher when he/she starts to teach for the first time.

When looked at different dictionary definitions, the word mentor means "a wise adviser" according to etymonline.com (see Appendix). The Merriam-Webster Dictionary defines it as "a trusted counselor or guide; tutor, coach". Synonyms of the word are listed as adviser, guide, confidant, confidante, counsellor, consultant, and therapist, as listed in oxforddictionaries.com (see Appendix). The first recorded use of the word dated back to 1616 according to Merriam-Webster (see Appendix). Yet, etymonline.com states that the word originates from Homer's Odyssey, in which Odysseus's friend, Mentor, is asked to take care of Odysseus's son, Telemachus, while the father is away at war and may never be able to come back again.

The person who learns something from the mentor is called the "mentee". According to Merriam-Webster, mentee means one who is being mentored, a synonym of which could be protégé, whose first known use was recorded in 1965. The mentee is protected or trained or his career is furthered by the experienced coach.

\section{Literature Review}

A lot has been said, researched, and written about mentoring over the past 30 years. School administrations integrate mentoring into their professional development schedules, if any. The reason why some school administrators do insert mentoring in their professional development activities is that it is highly useful on the institutional level, especially when teachers are asked to design curricula and define goals and policies for their schools (Hudson, 2010).

Apart from the institutional level, mentoring is a huge contribution both for the mentor and the mentee's professional careers (TANG \& Choi, 2005). Teachers who mentor the new coming teachers become advanced in that field and feel themselves more equipped when it comes to questions related with how to teach something or what to do in a certain situation. Similarly, the mentee will feel much safer after taking some mentoring from an experienced teacher and thus, will not have as many difficulties as anticipated when he/she starts teaching in the real classroom.

Mentoring studies can also help the development of the schools, their education systems and communities that are associated with that school, as stated by Galbraith (2003), Beutel and Spooner-Lane (2009), and Hobson, Ashby, Malderez, and Tomlinson (2009). Mentors will have a broader vision thanks to working with respectively young teachers and thus will be able to design a curriculum which is a synthesis of both the old and the new approaches and/or trends. In addition, mentors will always have to stay up-to-date, which will be another advantage for the school. Mentees will be the ones who carry this new atmosphere into the classroom, along with some traditional ways of handling some difficult situations at times.

Mentoring is a kind of an orientation study for a beginning teacher, but it is also a kind of reminder for an experienced teacher. Thanks to mentoring, the experienced teacher will have the opportunity to remember what stages he/she has been through and he/she can reflect on that while trying to make that thorny process much 
smoother for the beginning teacher. It is not highly possible to have professionally trained mentors in all schools, so some institutions have to do with what they have: more experienced teachers. Therefore, it is difficult to talk about lots of guided and associated mentoring studies in the majority of schools (Zeichner, 2010), which brings us to the problem of wanting to carry out mentoring workshops, but not having the ideal opportunities.

According to Giebelhaus and Bowman (2002), mentors contribute something to their own skills as well as to the mentee's. Mentors do not only teach in the classroom, but they also help a novice teacher get to know the "neighbourhood" and the "rules of the play", which should give them more satisfaction with what they have been doing. When evaluated as a whole, it can be seen that most mentoring studies circle around the benefit of the learners, but still, this will not hold mentors and mentees back from developing professionally.

\section{Methodology}

The study consisted of mainly three steps which can be seen under the heading of Instruments.

\section{Purpose of the Study}

The purpose of the study was to try to find out if mentoring could be helpful for someone who is not a new teacher in the job, but a new in the workplace, and if it could help the mentor revive some of her skills and competencies other than teaching. The researchers aimed to see what the reflections of both teachers would be after this extraordinary study.

\section{Participants}

The participants of the study were two teachers working at Gaziantep University, School of Foreign Languages. The mentor was an English instructor working at the same institute for 24 years. She is a graduate of an ELT (English Language Teaching) department. The mentee is an English instructor with seven years of experience. She graduated from an ELT department, too, and she had taught at two different private universities in İstanbul before moving to Gaziantep.

\section{Instruments}

Throughout the study, the participants were asked to follow the program prepared by the researchers and talk about each point in each session.

(1) Audio recordings of the sessions. The participants were asked to audio-record their sessions. They did that via their smartphones and sent them to the researchers immediately after each session so that the researchers could transcribe them before they all piled up.

(2) Mentee's teaching journals. The mentee was asked to keep a weekly teaching journal in which she could reflect on what she thought about the mentoring study and what she experienced in class during that week. The mentee sent the journals to the researchers at the end of each week.

(3) Mentor and mentee's reflections on the study. The researchers met the mentor and the mentee one by one and asked them questions after the four-week giving and taking sessions were over. The sessions were recorded and transcribed by the researchers.

\section{Data Analysis and Findings}

At the beginning of the study, 30.03.2017, the researchers of the study brought the two teachers together and 
introduced them to each other. They also explained the details of the study, gave them the program, and wished them luck.

The two teachers started to get to know each other briefly and decided on the lesson time they were going to observe each other. This initial week, April 3rd-7th, 2017, was only for the purpose of the teachers' observing one another. For one whole week, the new-coming teacher attended all classes with the senior teacher and observed her while she was teaching. On the last day of that week, the new-coming teacher also had the opportunity to convey a lesson with the group of students she had been observing. This time the mentor teacher observed her. The two teachers also decided on the dates when they were going to come together to talk about the issues determined previously by the researcher.

\section{Week 1: 12th April, 2017}

The two teachers came together to share the lesson plans. The senior teacher provided the necessary pacing schedule(s) for the mentee. She told her that there were different levels and, therefore, different schedules. The atmosphere was important - the mentor created a very constructive medium, saying:

"I can learn some techniques from you, and you can learn something from me, too".

They then decided to come together every Wednesday and Friday, whenever possible. On Fridays they were going to talk about the whole week and how everything had been so far. Because the two teachers had also been matched as partner teachers, they extended the talk by mentioning who was going to teach what skills and how they were going to assist each other. The mentee learned that the load for a B2 level class was 20 hours a week and that the 15 hours belong to the main course teacher. The partner/skills teacher had to continue with the remaining five hours.

The mentor teacher mentioned the course book and the skills books and checked whether the mentee had the correct books for each level and skill. The mentor then started to talk about how she normally unfolded a lesson. She explained that she tried to stick with the course book if she liked the flow of the starter and warm-up activities; she generally obeyed the order of the book and continued to present the core grammar and vocabulary according to the sequence in the book. However, she added that if she did not like the design of the lesson in the book, she immediately talked about the grammar of the unit in an isolated way, but then she tried to bridge it to the unit. She asserted that this was a beneficial method sometimes, but that it should not be always used. She then told the mentee that she could take initiative and do it this way if that is the case in her class as well.

The mentor moved on by saying that teachers should be able to decide whether the level of the unit is convenient for students' level of comprehension, and he/she could make modifications if necessary.

Mentor: We use ELS, for example. Do you know that book?

Mentee: No, I haven't used it before.

Mentor: It belongs to... It is a book... It has four levels. You can use it. It is an amazing book. Here I have it.

Mentee: Right, I know that book.

Mentor: Yes, It's a very good book. I can share it with you whenever you want. I have a lot of other resources in PDF format. I can share them as well.

Mentee: That would be great.

Mentor: I also use some grammar tests from the Internet. I can give you the links. 
Mentee: Thank you.

It is obvious that the mentor gave the mentee a lot of freedom while teaching, especially grammar. The mentor was also very cooperative throughout the first meeting, and so was the mentee:

Mentee: And I use Oxford Living Grammar. That is a very good book, too.

Mentor: Really? I don't know that book.

Mentee: OK. I can bring it to you. It is a very good book because it teaches grammar as it is used in everyday English. Of course it provides mechanical exercises.

But it's the best book I've seen so far.

Mentor: Wow! What was the name again? Let me note it down.

The two teachers also referred back to their previous experiences:

Mentor: ... We used this book while I was a student at university. This is the book I have learnt grammar from. I have been using it with my classes now and then. It is good because it starts with dialogues.

Mentee: Dialogues? OK. Isn't that available in new editions?

Mentor: No, it isn't, that's why I keep it. See, I graduated from university in 1992, and this is a 1985 edition. It's so valuable.

Mentee: (Talking about Oxford Living Grammar) I used it in my private lessons back in Istanbul. My students liked it. The activities and the exercises are really good.

The mentor and the mentee then went on to talk about how the Reading and Writing lessons are shared and conveyed in class. The mentor explained that she believed it would be good for the main course teacher to do the Writing classes as she has more time with the students and this meant that no subject or writing topic would be incomplete. However, she still made it clear that it depends on the two partners' agreement. She insisted that it was an issue to be necessarily talked about by two partner teachers of a class.

The mentor then moved on with the details of the writing classes, the correction symbols, and the portfolio files. She once again offered to share her materials with the mentee.

This session's issues could be summarized as flexibility, freedom, sharing, and negotiation.

\section{Week 1: 14th April, 2017}

The mentor started talking about the exam procedure. She told the mentee that all teachers had to gather in the Conference Hall prior to each quiz and module exit exam. She added that it was essential to be there on time because there could be some last minute announcements and it was important not to miss them. She added that there were four quizzes in each module, three of which had a Listening part; therefore, the mentee should follow the pacing schedule and take her CD player to the Conference Hall for those quizzes as she would have to rush to the classroom immediately after the short meeting. The mentor elaborated on the exam procedure by saying that we, as a school, never make any Turkish explanations. She warned her against some cunning students' tactics - they would try their chances with a new teacher.

She explained what the mentee was expected to do step by step during each exam, adding that the exam was going to be graded by the teacher who was in the classroom that specific hour regardless of whether it was a 
Writing quiz or a Grammar quiz. The exam papers were shown to students and after the corrections, if any, the grades were put on the system by the main course teacher.

The mentor went into the details of the module exit exams as well. She said that there were different sections of the module exit exams and that the teachers are informed about their assignments via emails from the administration. She highlighted that it was important to follow the emails.

The mentor said that the Speaking exam had been applied for the first time this year, which surprised the mentee. The mentor then explained that in the previous years the speaking part was administered by American teachers, but this year since Speaking was not an independent course and since it was embedded into the whole program, it was graded by all the teachers.

The mentee was quite interested and asked a lot of questions as to whether there were any Speaking sections in the previous year's Final and Exemption exams. The mentor answered that this was the first time that it was being applied that way. She then corrected what she had said previously: There was the Speaking section in the previous years, but not in the Final and Exemption exams.

The pair then started to talk about the Writing exam. The mentor said that the Writing exams had been evaluated by two checkers and that although it was announced by the administration, it was up to the teachers' preferences to be the first or second checker. She once again mentioned how important it was to negotiate between partners both on being the first or second checker and on what to do when there was a difference between the two graders' scores.

They started to talk about the main part of the Module Exit Exam finally. The mentor talked about the question types, which the mentee wanted some extra information about:

Mentee: What about these question types? Were they always like this?

Mentor: No, they weren't. In the course of time, we decided to change some parts.

Mentee: Why was that?

Mentor: Because we realized that some question types were not in accordance with our students' needs and competencies. Then we felt the need to update our exams and questions. We don't make these changes very often, though. The closest one I remember was some 10 years ago, when we decided to switch to skill-based exams rather than grammar-based exams.

Mentee: You said that there were American teachers before and they did the Speaking parts. What happened? Why did you change that? Why did you integrate Speaking into the main course?

Mentor: Well, there were some complaints about the program. Students had to stay at school for one extra lesson, and although they were having fun and they got high scores on that part, they could not talk when the main course teacher asked them some questions to express their opinions about. So we decided to do it in a different way this time.

This small talk could be commented on as a kind of self-criticism on the mentor's side.

The teachers then talked about attendance:

Mentor: It depends on the teacher, but normally, a student will be signed absent if he does not come within the first five minutes of the first lesson. However, since this new campus is so far from the city-centre, and because there are so many problems with transportation, I personally do not sign 
them absent. Ahmet is a good example here; I know that he does his best to reach school on time. But if I get the impression that the student has turned that into a habit, then I have no mercy. Muhammed in our class is one such student. By the way, it's only the first classes I'm talking about.

It is obvious that the mentor cares about punctuality, but she also sympathizes herself with her students.

The pair continued to talk about different topics, such as Teacher's Evaluation Grades, Self-Access System Grades, and Extensive Materials. The mentor thanked the mentee here:

Mentor: ....Yes, I see some of the words on the whiteboard when I enter the classroom after you. I appreciate that.

Mentee: Well, because they don't have any chance to use them outside class, I think, so I check them frequently. And because I don't want them to be disadvantaged in the exam.

Mentor: That's very good.

This week's session ended with the issue of time management. When the mentee confessed that she had a problem with time management this week, the mentor told the mentee that it was normal to sometimes fall behind the schedule or be ahead of it, but it would not be a big deal if the two teachers cooperated:

Mentee: The schedule was a bit overloaded this week, so I couldn't do the Reading activities this week; I mean, I had some problems with time management this week.

Mentor: This is quite normal because you are new, trying to know the students.

Mentee: Yes, and there was some extra grammar.

Mentor: Well, no problem. You could talk about this with your partner and he/she can help you with it-who, in this case, is me. I'll help you. Don't worry. Whenever you feel that you don't/won't have enough time, just talk to your partners. Or you could assign some activities to your students.

Mentee: Oh, yes. Thank you.

This session's important ideas were tactics, self-criticism, obedience, time management, and cooperation.

The mentee's reflection on time management and her way of teaching can be seen in her journal entry:

This week in terms of time management I was better than last week. I covered all the reading materials even though I also had to cover extensive readings for the first two weeks. I spent less time on discussion questions and speaking while focusing on the target vocabulary more. Sometimes I did the exercises together with the students-normally I give them some time first, after they are done, I check with the whole class, which of course saved me some time.

\section{Week 2: 17th April, 2017}

In this week's first session, the mentor and the mentee started to evaluate the previous week as they had failed to do so in the last session. Still, the mentor asked the mentee if she wanted to ask anything further about the schedule, but the mentee said that everything was crystal clear in her mind about the pacing. Thus, the mentor suggested talking about different level students and their characteristics. The mentee immediately agreed as she was teaching four groups in two different levels. 
Mentee: The lesson goes much better with the B2 group. They always join class discussions. They always do their homework.

Mentor: Really?

Mentee: Yes. Only one or two students failed to bring their homework, but it was a busy week for them last week.

Mentor: That's good to hear. And, the Repeaters? I guess you have to use a lot of Turkish in class.

Mentee: Yes, I do because if I don't make any Turkish explanations, I'll lose them all; they won't understand.

Mentor: So, you can see the difference yourself.

Mentee: Yes. And most of them are in a kind of relaxed mood.

Mentor: The repeaters?

Mentee: Yes. I think they think like "I can't fail any more. This is the end of the year".

Mentor: Which must be disturbing for you.

Mentee: Yes, but on the other hand, the Repeaters take their homework more seriously.

Mentor: Really? You're kidding me.

Mentee: No, I'm serious. I talked to them so much that...

Mentor: I see; you made them feel themselves...

Mentee: Important...

The mentee emphasized that she made the students realize their own mistakes as follows:

Mentee: When I talk to them, they say, "It's our fault. We didn't study before". I tell them that I really take them dear and that their doing the assignments is important for me. Then, they realize that the reason they failed is not only the fault of the system.

Mentor: That's a super diagnosis on your side! I appreciate that.

Mentee: Thank you. I mean I do these things as extras; and yes, in fact, they don't have to do them. But if I make an effort for them, then they should struggle to survive, too. I want them to become aware of that.

Mentor: Very good; very good!

Mentee: You see, in fact, I don't see much of a difference between B2 and B1 students.

Both the teachers agreed on the fact that if students believe that the teacher's attitude is real and intimate and that the teacher does that for the students' good, then they feel encouraged and they start to study. They sympathized again with one student who said that he/she was the youngest of two siblings and that he/she was never given the right to speak in the family, concluding what a valuable experience it must have been for that student to be given the chance to speak.

This sessions' main interests seemed to be motivating students, especially weaker students, and raising their awareness on being a precious individual. However, what really came out was the value the two teachers attached to each other's attitude and way of thinking. 


\section{Week 2: 21st April, 2017}

The two teachers went over the issue of motivation again in this session as this was going to be a wrap up session. They talked about what generally caused students to lose interest in the lesson and what they could do to motivate their students. In the course of their small talk, the two colleagues agreed on the fact that students could easily get lost when the subject is beyond their scope and that they would easily be distracted, or vice versa. They also agreed on the fact that when students' motivation gets down, the teacher's motivation is also badly affected. Thus, each side should do their best to keep motivated. The mentee suggested that they could make the students play Taboo, as she had experienced that with learners of different age groups. She said that there were some cultural things in Taboo, but she believed that these would help students improve their language skills. It was impossible to think of language without culture, both teachers thought, and they gave a message to the Administration so as to have more cultural aspects inserted into the program in the form of competitions among groups, just to illustrate. However, they both thought that it may not be possible because of the class sizes at the state university. Remembering the mentee's previous experience at a private university and that the present situation at state universities is a bit far from those at private universities should be kept in mind, they concluded.

One other main finding of this session was that the more time spent with the same students, the better a teacher holds a relationship with them. He/She gets to know them better, and thus provides the teacher with an opportunity to know which student is following the lesson; which student is pretending to be following the lesson; which student is bored; which student needs a break, or it makes the teacher wonder about a student if one student is absent in that particular lesson, as, say, he is a regular student generally. The quotation from that teacher (the mentor) is as follows:

Teacher: Where is Anll? Interesting, he hasn't come today.

Student: Ma'am, how did you realize that he always comes and is not here today?

Teacher: I can read your mind and whatever is inside you.

The mentee reflected on this week's contribution of the program to her teaching in her journal as follows:

Upon the request of the main course teacher, I teach course book in one of the B1 level classes. I think it is a good chance for me to experience teaching main course book too. This week, I also did writing with them by giving feedback on their paragraphs and essays so I had another chance to teach writing skill. As Lara teacher told me the procedure in writing lessons, portfolios and grading before, I was prepared already. Thanks to her guidance, I don't jump into an unknown and lose time in catching up with the lessons.

\section{Week 3: 24th April, 2017}

In this week's first session, the main concern was to talk about problem areas in teaching and grading. The mentor started talking about the most controversial component of language when it comes to testing: writing. She explained the main procedure for the Portfolio File requires students to write a paragraph/essay in class, give it to the teacher, and take it back from the teacher with correction symbols on them. This first draft was graded and then the students got a second score after they corrected their first drafts. The average of these two grades was going to form the first grade of three portfolio assignments. 
The mentor also explained the grading of Module Exit Exam Writing papers. She said that this time there were two checkers, as she had previously explained briefly, and that if there is a difference of 20 points or more, the checkers needed to come together to grade that paper again. She also added that it was important not to see the first checker's grade in order not to have a biased attitude. The mentor additionally stated that there was a rubric to be followed. She told the mentee that she believed it was important that the student could give his message this or that way and that it should not be the aim of the teacher to take off all the points if the student makes grammar mistakes. She imposed the mentee that we should grade students on what or how much they can accomplish rather than what they cannot.

Mentor: ...Sometimes our students may not use high level vocabulary, but we know our students' capabilities. It is unfair to cut off 15 points if the student could not make use of some kind of advanced vocabulary, I think. I believe that we should grade the student on how much he could state his opinion or feeling. Similarly, in spelling which is worth 10 points, I never give nine to a student who has made one or two spelling errors; that's unfair I think.

The mentor and the mentee continued to talk about the rubric in detail comparing the private university and state university case. They both agreed that teachers should not be too strict while grading students' Writing performances.

Mentee: ...I agree with you. The student may have poor grammar, but his content may be good, so I do not think we should punish the student by taking off his grades. Of course, he should get a low grade on the grammar part of the rubric, but he should not affect his content grade. Otherwise it would be both unfair and discouraging, leading the student to lose faith in himself. I think minor mistakes can just be ignored.

Mentor: I couldn't agree more.

The teachers then moved on to talk about how they dealt with Writing in the classroom. They once again went over the fact that it is generally the main course teacher who takes the responsibility of teaching writing in the classroom. The mentor mentioned that in some exceptional cases, the partner teacher came to the main course teacher and offered to evaluate one Portfolio application at least, at which both teachers laughed heartily. The mentor added that she had been doing the Writing classes on Tuesdays and Wednesdays, as students were generally tired at the beginning of the week and towards the weekend, thanks to her experience over the years.

The mentor told the mentee how she made her class write an essay collaboratively after the outlining has been finished altogether, which the mentee appreciated deeply. The mentor admitted that it was a time-consuming activity, but she also added that it was a very fruitful activity on behalf of students' improving their ability to write. The mentee stated her admiration as follows:

Mentee: I can make use of this activity when I teach Writing in the future. You know, writing looks like a passive activity to most students; however, they can be very 
active using this method. I'll definitely use it.

This session's remarkable issues could be summarized as being constructive while grading and creative and patient while teaching.

\section{Week 3: 28th April, 2017}

This session, the teachers were going to talk about school culture. The mentor stated that they had already talked about certain issues, such as the schedule, the workload, exams, exam procedure, and the grading of exams, so it was now time to "gossip" about relationships among teachers, relationships with students, and some unwritten rules at school.

The mentor assured the mentee that whatever they spoke would be confidential if she had experienced any negative things since the day she started working here. The mentee said that she had not and added that all the experiences she had had were positive until that moment. She said that all the colleagues here were smiling and welcoming, offering help each time they saw her. She also added that she felt more relaxed in this new environment especially when she compared it with her previous workplace, where she had to work from 8.00 to 5.00 every day. The mentor and the mentee went into a dialogue as follows:

Mentor: It's really different, right; I mean, working in a metropolis like Istanbul and then starting to work in a smaller city like Gaziantep.

Mentee: Yes, I mean in the hassle of Istanbul, everybody leads a more isolated life, but here in Gaziantep, the social bonds are much stronger. I can observe this easily here, but maybe it's also because of the workload difference between the two workplaces; I mean, we really worked hard there and we got exhausted. We were not just teaching, we were also making translations constantly and preparing webpages. We, 60 teachers, could rest in a long corridor, tables arranged one next to the other in a long corridor with no windows and with the lights on constantly.

Mentor: Really? At a private university?

Mentee: Yes, believe me.

Mentor: Kübra, you need to tell this to all our teachers here! You know what, this is a new building for us, and the administration decided on which office was going to be given to which teacher-we didn't ask for any specific office. The senior ones were given single offices with windows, and the more recent teachers were given offices to be shared with one other partner, some of them with windows, some of them facing the corridor. You should have seen the chaos that created!

Mentee: I don't believe it.

Mentor: That was the case, right.

Mentee: They should compare themselves with me.

The pair talked further about this problem and they said that people were lucky here because they did not have to be at school from 8.00 to 5.00 every day. The mentee also added that they could visit each other in their offices, which was none of her options back in İstanbul. 
The mentor added that although they were more social when compared with İstanbul, they had become less sociable over the years, especially when remembering those good old days when they were smaller as a department in size and when they could all come together during the lunch break in the city center and then come back to the old campus for the afternoon classes. She added that keeping social was becoming harder when the staff rose up to about 100 teachers in the same department. The mentee showed her surprise saying:

Mentee: Really? I thought of the whole new workplace as an advantage. I mean that's the advantage of living in a small city. They were all very helpful, especially Ayşe and Nevin. They were always supportive. They informed me about everything and guided me. I wouldn't find such a thing in a big city. This was an extra bonus on my side. It makes me feel happy.

The mentor and the mentee agreed on the fact that the environment and the city one works in affects not only his/her performance in the workplace, but also their motivation directly. They also shared the same idea that becoming bigger in numbers brought social isolation along with it and they asserted that in order to prevent social isolation, what an individual needs is not being part of a big, social group; on the contrary, being a part of a small, intimate group is sufficient.

The main issue arising from this session could be summarized as the impasse among heavy workload, big city, and social relationships. The heavier the workload gets, the more the city expands, the less people have to share with each other in terms of friendship. This, according to both the teachers, is what makes the job more difficult or stressful.

The mentee reflected on the importance of social relationships in her journal:

From the very first day, every colleague has been very kind and friendly to me. Especially Ayse and Nevin have always been there whenever I've needed something; they have informed me about nearly everything. I've moved to a new city, which was unknown to me before, and started a new life without knowing anyone but with their existence, I haven't felt alone at all. I believe the people you work together with are of the same importance as the workplace and the students. Having a positive communication with the colleagues is always a good motivation and I'm happy that there is a warm atmosphere in our workplace.

\section{Week 4: 4th May, 2017}

The mentor started to talk about how the academic and administrative issues are announced in the workplace. Although they had talked about it earlier, she reminded the mentee that all the information flow in the workplace is generally maintained through emails. However, this time she went into a bit more detail saying that if there is a change in the grading of a question on a quiz, for example, teachers were informed of that via emails, as well.

The mentor also made a comparison between the past and the present day, stating that in the past, they used to have meetings after each quiz to talk about some problematic questions, if any; but she added that this was no longer possible because there were too many teachers and too many ideas this time, which made it hard to come together and share their ideas for a short time. Her main concern was that it was hard to reach a consensus on any question in such a short break and she added that the administration and the testing office may be thinking in the same way, thus leading to the abolishment of those post-quiz meetings. 
Yet, she added that meetings were still held at the end of both the fall and the spring semester each academic year. She added that at the end of the semesters, teachers generally made an evaluation about how teaching had been going; what areas needed to be brushed up on; which areas were fine; which books met our needs, and which books needed to be changed.

Mentee: Are these meetings always held at the end of each semester?

Mentor: Yes.

Mentee: So the books are evaluated at the end of each semester?

Mentor: Well, for the books, yes. A committee has been formed in April or May, and they choose a book together. We are informed about that at the meeting.

Mentee: Why do you change the books?

Mentor: Well, it is generally because the book does not teach our students in the usual way; or because there is a need to update the contents of the book. In one of our Reading books, there was a text about the planets, and our students immediately objected to the information as it had been proven that there are more than nine planets in the universe. You can imagine, I guess.

Mentee: Oh, yes.

The mentee wondered about how feedback about the materials and books was collected from teachers. The mentor answered that first, they informed the coordinator about it, and then the coordinators talked about it in their weekly meetings. The coordinators then passed on this information to the administration. If the administration accepted the complaints/diagnosis, they assigned a committee to choose new materials and books. She also added that not everybody expressed their opinions about the books or materials, but used their initiatives about which parts to cover and which parts to skip in class, adding that she sometimes was one of those teachers.

The mentee agreed with the mentor and she added that because of the heavy academic load of the program, sometimes teachers had to end up skipping some daily English or everyday English parts, which are, in fact, more important than academic English in most circumstances. She also stated that when teachers did so, students lost their interest toward the content of the lesson. At this point, the mentor agreed with the mentee:

Mentor: Yes, especially this term, they feel so overloaded. When we come together with our colleagues in the break for a nice little chat, we talk about... For example, when we teach gerunds and infinitives, why do we focus on the difference between "remember" and "forget", rather than teaching them where they can really, I mean "really" use gerunds and infinitives. Why don't we teach them ESP? Our students are mostly engineering students, so why don't we teach them how to read fractions? Their motivation is much higher in such subjects. I know because we did that many years ago. ...But there was another problem-my English level was OK, but when students asked more detailed questions, I could not answer them because it was not my major. 
The mentor elaborated on this problem by stating her doubt about whether it was necessary to teach them the Future Perfect or the Past Perfect Continuous. The mentee agreed that it was more important to teach students the everyday and vocational aspects of English.

It could be said that in this session, the two teachers focused on the hierarchical structure of the school, how feedback turned into proof while choosing textbooks, and what really matters in the teaching of English: real English rather than superficial English.

\section{Week 4: 5th May, 2017}

As this was the last session, the two teachers evaluated the whole "Mentor for a Month" program. The mentor asked the mentee if she had found the program beneficial or not, to which the mentee answered as follows:

Mentee: Yes. To me, it was very beneficial. Especially,... I shadowed you in your classroom. When I first came here, I had no idea about how the lessons were covered and what the students' profile was. It was also good that I came in such a moment; I mean when this study was conducted. I didn't immediately plunge into teaching; I had the opportunity to observe what had been going on. That was, I think, very useful for me.... Students are so different here. Private university students are totally different; I could see that. I also learnt how you cover the lessons, and I got to know the textbooks. Your guidance was also very valuable for me. I had a lot of questions in my mind before, but you eliminated them one by one. Your sharing all your materials with me and all the extra information you provided for me... I found this period very fruitful.

The mentor also expressed her opinions on the program:

Mentor: It was beneficial from my side as well. This is the first time I have done something like that. Nothing like this has ever been done in our school before... I've been here for 24 years. We keep saying, "Let's integrate new friends to the program, to the school". I mean, our purpose is not to teach that person English again; we want to help him/her with how he could transfer his/her knowledge to the students; how he/she can do that easily; we want to make him/her familiar with the procedure or the system at our school. I feel that when we don't do this, the new colleague may have hard times at the beginning. I don't know how correct this finding of mine is; I mean I am a bit old now, and the new generation thinks differently. They think like, "If I ask them (older teachers) about this, they will have the impression that I don't know English", but they make mistakes when they don't consult us.

At this point, the mentor remembered the old days and told the mentee that at the beginning of her career, she and her peers used to consult more experienced teachers about a point when they were not sure about how to teach that in class, and she added that those experienced teachers were always very supportive and encouraging. She also added that she liked sharing what she knows with the younger generation because she felt that it was like sharing the place where you bought something nice with your friends and encouraging them to go there, too. She said that some friends might think of that like something too highbrow, but that it was not the case. She added: 
Mentor: ... because I had so many hardships when I started doing my job and because I don't want others to experience the same, I like sharing what I know with people who consult me. I also liked sharing this experience with you. I also learnt something from this program on my behalf.

The mentor also reflected on the use of this program by saying:

Mentor: I have been working here for 24 years, but if I had to go and start to work in another institution, I would like to get through a similar orientation process. I feel that I need a lot of hands-on information about the system, the unwritten rules, the students, etc., from somebody who is from the very heart of the system there.

The mentor then felt the need to check on what she had shared with the mentee and the mentee reassured her that everything was fine:

Mentor: I believe that the unwritten and informal rules are very important in the operation of the teaching process, and I hope I haven't left out any part on this when it comes to our case. I hope I have provided you with all the necessary information you need to survive here.

Mentee: I think you haven't left anything out. I feel well-equipped now. Thanks to your orientation, I prepared myself very well. For example, when I started actual teaching here, I didn't have questions on my mind related with the system here. I was psychologically relaxed as well owing to our talks.

In the final session of the program, both the mentor and the mentee said that they had learned new things and stated that it had been highly efficient for each one. The mentor added that she, no matter how long her experience was, would definitely be in favor of something similar to be done for her should she go to another school. The two teachers supported the study and said that it was a good guide for the mentee to have her way enlightened; and a good opportunity for the mentor to share her knowledge and experience with a younger colleague and get to know some different ideas on the younger generation's approach to the job of teaching.

When looked at the mentee's journal entry for the last week, it can be seen that she found the study really worthwhile:

This week we finished our mentoring sessions with Lara teacher. I think they were really helpful in my adaptation process. She guided me through this process and answered all my questions related to the schedule and the preparatory program. Thanks to her, I was prepared for new classes and I got familiar with them beforehand. She also introduced me to other teachers. Thanks to the help of my mentor, administrators, and colleagues, I could easily adapt myself to the program and through their guidance; I proceeded without having any difficulty. I think I have been lucky to work with a caring and friendly team; it has been much easier for me to start in a new city and at a new workplace.

After the program finished, the researchers came together with the mentor and mentee separately to ask some further questions. The questions and the answers for both the mentor and the mentee are as follows: 
(1) Was it a useful project? If yes, especially on what aspects was it useful?

\begin{tabular}{l|l}
\multicolumn{1}{c|}{$\begin{array}{l}\text { Mentor } \\
\text { The mentor stated that she found the program } \\
\text { useful, especially sharing what she knows with a } \\
\text { colleague made her happy, as she is a cooperative } \\
\text { person in general. She also added that it was a } \\
\text { different experience for her. }\end{array}$} & $\begin{array}{l}\text { The mentee said that it was definitely a useful } \\
\text { project as through it, they could have a chance to } \\
\text { exchange their ideas about the program, the content } \\
\text { of the lessons, and teaching methods. She added that } \\
\text { the mentor's guidance was also really helpful for her }\end{array}$ \\
as she had just started to work at her current \\
institution and she did not know about the procedure \\
there. She stated that she got familiar with the \\
schedule, the lessons, and the students with her \\
mentor's help.
\end{tabular}

(2) What do you think about the matching bringing the two of you together? Was it appropriate?

\begin{tabular}{l|l} 
Mentor & Mentee \\
\hline $\begin{array}{l}\text { She thought that it was perfect. She added that } \\
\text { the matching was suitable since the mentee also had } \\
\text { eight years' experience, so they did not talk about } \\
\text { how to teach something in detail, but they focused } \\
\text { on how to teach more effectively. }\end{array}$ & $\begin{array}{l}\text { The mentee said that it was a good match and } \\
\text { added that the communication was much better } \\
\text { when they came together; this way they could } \\
\text { discuss issues in detail. They both felt comfortable. } \\
\text { It was more like a chat than a formal procedure. }\end{array}$
\end{tabular}

(3) Would it be better if two peers were matched?

\begin{tabular}{|c|c|}
\hline Mentor & Mentee \\
\hline $\begin{array}{l}\text { The mentor stated that matching two peers } \\
\text { would not be desirable, as she had doubt about what } \\
\text { the two could share with each other; none of them } \\
\text { would be experienced, so how would one guide the } \\
\text { other? }\end{array}$ & $\begin{array}{l}\text { The mentee frankly said that she had never } \\
\text { thought about whether it would be better if her } \\
\text { mentor were her peer. Yet, she added that she } \\
\text { thought if two peers are matched, they can still learn } \\
\text { something new from each other. Moreover, they can } \\
\text { feel more comfortable and feel closer as they might } \\
\text { have had similar experiences. The mentee further } \\
\text { said that in this project, her mentor was much more } \\
\text { experienced than she was, so it was really helpful to } \\
\text { learn about her methods and insights. She was like a } \\
\text { role model for her. }\end{array}$ \\
\hline
\end{tabular}


(4) Did the study/project have any handicaps? What we mean is that it was something that had not been tried before. Do you think it needs some final touch? For example, you can think about the length of your sessions, etc.

\begin{tabular}{c|c} 
Mentor & \begin{tabular}{c} 
Mentee \\
\hline The mentor stated that the only handicap could \\
be the length of their small talks_-sometimes they \\
did not realize how time flew while talking. Other \\
than that, there were no problems according to her.
\end{tabular} \\
$\begin{array}{l}\text { The mentee stated that except practice teaching, } \\
\text { she had never taken part in a study like this. She } \\
\text { thought that the length of the sessions could have } \\
\text { been longer as most of the time when they stopped } \\
\text { the recording; there were more things to say. She } \\
\text { suggested using a flexible duration for the sessions. }\end{array}$
\end{tabular}

(5) Which feature(s)/quality (qualities) of your mentor/mentee did you like best, or which feature(s)/quality (qualities) of hers would you take as an example?

\begin{tabular}{|c|c|}
\hline Mentor & Mentee \\
\hline $\begin{array}{l}\text { The mentor stated that she liked the mentee's } \\
\text { vocabulary teaching style as she was also } \\
\text { emphasizing the pronunciation of the word. She also } \\
\text { appreciated the mentee's beliefs about not being } \\
\text { slaves of grammar. She also liked the mentee's } \\
\text { positive attitude. }\end{array}$ & $\begin{array}{l}\text { The mentee said that she really liked her } \\
\text { mentor's friendly attitude. The mentor was always } \\
\text { positive and caring while guiding her through the } \\
\text { project, thus the mentee felt really comfortable with } \\
\text { her and could express her opinions freely. The } \\
\text { mentee also added that the mentor always made her } \\
\text { feel that she is another colleague of hers and she was } \\
\text { there to help her-not to give instructions to her } \\
\text { about how she should perform certain tasks in class } \\
\text { or show her how to teach. The mentee added that this } \\
\text { was really important for this type of a study. She } \\
\text { added that she enjoyed her guidance and the } \\
\text { sessions. She elaborated on that saying that she was } \\
\text { lucky to work with her and she learnt a lot from her } \\
\text { mentor. The mentee also stated that she saw the } \\
\text { mentor teach in class in a friendly manner, too. The } \\
\text { mentee would like to apply the mentor's teaching } \\
\text { methods in her classes in the future. }\end{array}$ \\
\hline
\end{tabular}


(6) Considering the institution, what benefits did/does the study bring to the department?

\begin{tabular}{l|l}
$\begin{array}{l}\text { Thentor } \\
\text { communication between the two of them, a kind of } \\
\text { co-operation/relationship between two colleagues, } \\
\text { which has been lacking in the department for a long } \\
\text { time. }\end{array}$ & $\begin{array}{l}\text { Mentee } \\
\text { It is always helpful to get feedback from the } \\
\text { admistrators, colleagues, and students about the } \\
\text { process of the lessons, the mentee said. According to } \\
\text { her, in order to move further, we need to look at } \\
\text { ourselves through the eyes of others. This type of a } \\
\text { study gives us a chance to observe if the program } \\
\text { works well or there are any issues to be solved and if } \\
\text { so, what solutions can be suggested to overcome } \\
\text { these problems. By exchanging different ideas and } \\
\text { points of view, more effective classes can be created, } \\
\text { she thinks. }\end{array}$
\end{tabular}

\section{Conclusion and Discussion}

Teaching is a job which requires constant learning, giving and taking, patience, and appreciation. It is one important component in the forming of a society. Ergo, it requires special care and treatment. One cannot stop learning after graduating from university, and, hence, he/she cannot go to the classroom in an isolated way. There will always be some interaction among teachers and this will affect the way they teach their subjects. Hence, teachers are in some respect mentors and mentees of each other.

As mentoring is continuing in lots of schools without teachers' being aware of it, implementing this valuable opportunity to share each other's experience and expertise in a formal and overt way in schools is worth considering. School administrators may try to make use of this interaction among teachers for better education. They may design some mentoring pairs or groups once each term and ask the teachers about their view on the benefits of the initiative, especially from the aspect of the participants' personal and professional development; they may also ask all administrators about their point of view and they may try to find out its benefits on the institutional level.

Curriculum designers for Teacher Education programmes may also try to embed the concept of mentoring more in their programmes and let prospective teachers become aware of it. They should emphasize that sharing is important in the school context and that sharing and guiding might help build a more positive future for countries.

\section{References}

Beutel, D., \& Spooner-Lane, R. (2009). Building mentoring capabilities in experienced teachers. The International Journal of Learning, 16, 351-360.

Galbraith, M. W. (2003). Celebrating mentoring. Adult Learning, 14, 2-3.

Giebelhaus, C. R., \& Bowman, C. L. (2002). Teaching mentors: Is it worth the effort? Journal of Educational Research, 95(4), 246-254.

Hobson, A. J., Ashby, P., Malderez, A., \& Tomlinson, P. D. (2009). Mentoring beginning teachers: What we know and what we don't. Teaching and Teacher Education, 25, 207-216.

Hudson, P. (2010). Developing and sustaining successful mentoring relationships. Journal of Relationships Research, 4(1), 1-10. 
TANG, S. Y. F., \& Choi, P. L. (2005). Connecting theory and practice in mentor preparation: Mentoring for the improvement of teaching and learning. Mentoring \& Tutoring: Partnership in Learning, 13(3), 383-401.

Zeichner, K. (2010). Rethinking the connections between campus courses and field experiences in college-and-university-based teacher education. Journal of Teacher Education, 61(1-2), 89-99.

\section{Appendix}

Mentee. (2017). In merriam-webster.com. Retrieved May 14, 2017 from https://www.merriam-webster.com/dictionary/mentee Mentor. (2017). In etymonline.com. Retrieved May 14, 2017 from https://www.etymonline.com/search?q=mentor Mentor. (2017). In merriam-webster.com. Retrieved May 14, 2017 from https://www.merriam-webster.com/dictionary/mentor 